\title{
DNA Barcoding of the Solanaceae Family in Puerto Rico Including Endangered and Endemic Species
}

\author{
Lumariz Hernandez Rosario, Juan O. Rodríguez Padilla, Desiree Ramos Martínez, \\ Alejandra Morales Grajales, Joel A. Mercado Reyes, Gabriel J. Veintidós Feliu, \\ Benjamin Van Ee, and Dimuth Siritunga ${ }^{1}$ \\ Department of Biology, University of Puerto Rico Mayaguez Campus, Mayaguez, PR 00680
}

\begin{abstract}
AdDITIONAL INDEX worDs. species identification, $p s b$-trnH, matK, ITS
Aвstract. The Solanaceae family is one of the largest and well-distributed plant families in the world. It contains species of agricultural and economical importance, such as Solanum tuberosum, Solanum melongena, Solanum lycopersicum, Nicotiana tabacum, and Capsicum annuum. In Puerto Rico, there are $\approx \mathbf{4 6}$ species of Solanaceae of which six are endemic: Brunfelsia densifolia, Brunfelsia lactea, Brunfelsia portoricensis, Goetzea elegans, Solanum ensifolium, and Solanum woodburyi. Our objective was to use DNA barcoding to identify the Solanaceae species in Puerto Rico, including the endemics, and to assess the species relationships between them. To accomplish our objective, two chloroplast regions (psbA-trnH and matK) and a nuclear region [internal transcribed spacer (ITS)] were assessed. Pairwise distance and phylogenetic analysis demonstrate that DNA barcoding can be used to discriminate at the species level among these taxa in Puerto Rico. For all three markers, the genus that showed the highest pairwise distance between represented species was Solanum, whereas the genus that displayed the least was Capsicum. Phylogenetic trees of single and concatenated regions were generated from sequences obtained in this study and from data downloaded from the National Center for Biotechnology Information database. Our results show that this technique can be used to identify species with one, two, or three combinations of DNA barcode markers depending on the taxon. In addition, this is the first study to include the endemic species $S$. woodburyi in a molecular phylogenetic analysis, and it was found to have a close relationship with $S$. ensifolium, also endemic to Puerto Rico, and to Solanum bahamense from the Bahamas and Greater Antilles. Therefore, we suggest that $S$. woodburyi might be part of the Bahamense clade.
\end{abstract}

The Solanaceae family is one of the major groups of angiosperms with $\approx 2500$ species and 100 genera (Filipowicz and Renner, 2012). The family contains species with agricultural and economical importance worldwide such as Solanum tuberosum, Solanum melongena, Solanum lycopersicum, Nicotiana tabacum, and Capsicum annuum, as well as numerous toxic or poisonous species. Puerto Rico is considered a biodiversity hotspot due to its tropical location and the high concentration of endemic species that have been threatened by habitat loss (Helmer et al., 2002; Myers et al., 2000). According to Axelrod (2011), in Puerto Rico, there are 46 species of Solanaceae from 14 genera. Of these 46 species, Bunfelsia densifolia, Bunfelsia lactea, Bunfelsia portoricensis, Goetzea elegans, Solanum ensifolium, and Solanum woodburyi are endemic. Some of these species are endangered or rare, with only a few studies conducted on them.

Received for publication 5 May 2019. Accepted for publication 15 July 2019. The authors thank José A. Sustache (former Natural Resources employee) for all his help facilitating plant material, as well as Anastasio Gomez. We also thank Manuel Sepulveda (coordinator of the Jardin Botanico de Rio Piedras), Christian W. Torres Santana (former Director of Fundación Comunitaria Luis Muñoz Marin), Jose Rene Román (Guajataca Forest Management official), Hector Serrano (Cayey Forest Management), Miguel (Papo) Vives, and Henry E. Hernandez Rosario for their help collecting specimens. In addition, the authors thank Clinton Morse, Dr. Gregory J. Anderson, and their team from the Biodiversity Education and Research Greenhouse of the University of Connecticut for sending us plant material of Solanum ensifolium from Cayey, Puerto Rico. Special gratitude is extended to Jeanine Vélez, curator of the University of Puerto Rico Mayaguez-MAPR herbarium, for providing dried plant material. This project was supported by a grant to DS from the U.S. Department of Agriculture Hispanic Serving Institutions (HSI) program (2016-06469).

${ }^{1}$ Corresponding author. E-mail: dimuth.siritunga@upr.edu.
Filipowicz and Renner (2012) included the endemic and nonendemic Brunfelsia species of Puerto Rico in their systematic study. They hypothesized that these species reached the island 3 to 5 million years ago, and their seeds were dispersed by birds from South America. In research by Muscarella et al. (2014), the Puerto Rican endemic Solanaceae species $G$. elegans and S. ensifolium were included as part of the trees of Puerto Rico that were evaluated. They studied $89 \%$ of Puerto Rico's trees to analyze the community phylogeny based on regions with different climate areas.

In Puerto Rico, there are two endemic and endangered Solanaceae species: G. elegans and S. ensifolium. In 1985, G. elegans was listed by the U.S. Fish and Wildlife Service under the Endangered Species Act. At that time, there were fewer than 50 individuals in three known sites (U.S. Fish and Wildlife Service, 1985). More recently, this species has increased in number of individuals and has been reported to be present in 10 localities, but it still is considered an endangered species (Vargas, 2013). Comparatively, the species distribution and status of $S$. ensifolium is less known, as it has not been evaluated since 1992. In 1992, 150 individuals were found in the locality of Las Tetas de Cayey (Vargas, 2015). It was hypothesized that the species could be present in other localities, but that has not been confirmed. Unfortunately, during this study, S. ensifolium was not found in Las Tetas de Cayey or at other localities where it was thought to be, such as in Florida, Puerto Rico. Its presence at other localities is currently unknown. Due to Hurricane María in 2017 , there is a high possibility that $S$. ensifolium might be even more critically endangered than in 1992, and in the worst-case scenario, it has gone extinct in the wild. More 
studies and conservation efforts are critically needed to determine the current status of $S$. ensifolium.

In addition, studies of rare species such as the endemic $S$. woodburyi are also needed, especially using molecular tools. This species has not been classified as endangered, but only a few individuals are known to be present in specific localities, such as the Sierra de Luquillo (Axelrod, 2011). Our study is the first to include $S$. woodburyi in a molecular study. Previous research on this species has focused on the description of the species in a synopsis of the endemic species of the West Indies (Howard, 1966; Knapp, 2009). Of the 46 Solanaceae species found in Puerto Rico many, such as Jaltomata antillana and Solanum polygamum, are not well studied with no molecular data available in public databases such as GeneBank. Therefore, we apply molecular techniques, specifically a DNA barcoding approach, to better understand the species relationships and delimitations for the taxa of Solanaceae in Puerto Rico.

DNA barcoding was proposed as an easy and cost-effective technique for the identification of species. It consists of the amplification of a universal, robust, and standard region. The first region proposed for this analysis was the mitochondrial gene cytochrome c oxidase I (COI) for animals (Hebert et al., 2003). It has been successfully used in studies of taxonomy, population genetics, forensics in wildlife crimes, and conservation and in species identification in cases of fish mislabeling, among others (Cywinska et al., 2006; Di Pinto et al., 2015; Hebert et al., 2004; Rolo et al., 2013). In plants, the use of the COI region is not recommended for DNA barcoding studies due to its low evolutionary rate (Kress et al., 2005). DNA barcoding for plants has been more challenging than for animals, and more than one barcode region is needed for species identification. Currently, the most accepted and widely used regions in DNA barcoding studies in plants are $r b c L$, matK, $p s b A$-trnH, and ITS (Bolson et al., 2015; CBOL Plant Working Group, 2009; Kress, 2017; Li et al., 2014). Different studies have shown successful identification of species using a combination of these barcode markers, but some studies have also found limited ability to discriminate species within groups consisting of recently diverged species (Collins and Cruickshank, 2013; Kress, 2017; Kress et al., 2009; Muscarella et al., 2014; Spooner, 2009).

In this study, the barcode regions used were two chloroplast regions and a nuclear region, matK, psbA-trnH, and ITS, respectively. The mat $K$ region is $1500 \mathrm{bp}$ long and encodes for maturase-like polypeptide, which is believed to be involved in Group II intron splicing (Selvaraj et al., 2008). It has an evolutionary rate suitable for distinguishing taxa at high taxonomic levels such as order, family, and, in some cases, at the genus levels (Yu et al., 2011). For a coding region, matK has higher variability compared with $r b c L$, but it has not been successfully amplified in all plants (such as gymnosperms). However, it has worked well for angiosperms (CBOL Plant Working Group, 2009; Dunning and Savolainen, 2010; González et al., 2009; Hollingsworth et al., 2011; Kress and Erickson, 2007). Because matK cannot distinguish at lower taxonomic levels, it is usually combined with other regions such as $p s b A$-trnH, which has a higher substitution rate (Hollingsworth et al., 2011). The $p s b A$-trnH region is an intergenic spacer of $\approx 400$ to $500 \mathrm{bp}$ in length. Because of its variability, it has been demonstrated to discriminate successfully at the species level when combined with other barcodes (Bolson et al., 2015; Kress and Erickson, 2007; Kress et al., 2009; Štorchová and Olson, 2007).
For discrimination at the species level using DNA barcoding, the nuclear internal transcribed spacer (ITS) region been successfully used to complement chloroplast barcodes (Kress et al., 2005; Li et al., 2011). The internal transcribed spacers (ITS1 and ITS2) are between the nuclear ribosomal 18S-5.8S$26 \mathrm{~S}$ genes, and altogether the marker consists of less than 700 bp (Feliner and Rosselló, 2007). Although ITS has helped discriminate at the species level, there are two main concerns when using it in DNA barcoding studies: the possibility of amplifying the ITS region from fungal contaminants and the amplification of divergent paralogous copies (Hollingsworth, 2011).

Our overall objectives in this study were 1) to understand the feasibility of using DNA barcoding for identification of Solanaceae species found in Puerto Rico and 2) to study the phylogenetic relationships among the endemic and nonendemic Solanaceae species of Puerto Rico.

\section{Material and Methods}

Sample collection. Permits from the Puerto Rico Department of Natural Resources (2016-EPE-032/O-VS-PVS15SJ-00854-11072016) and the U.S. Fish and Wildlife Service (41521-2017-08) facilitated the collection of samples from protected areas. Using the location data of previous Solanaceae collections from the University of Puerto Rico Mayaguez's Department of Biology herbarium (MAPR), 53 samples were collected from different field localities in Puerto Rico. Furthermore, 13 samples were collected from the Jardin Botánico of Puerto Rico, Fundación Luis Muñoz Rivera, Guajataca Forest, Rio Abajo Forest, and Maricao Forest. In addition, six samples from the MAPR herbarium were used in this study.

DNA Extraction. The DNA was extracted from fresh samples using the Doyle and Doyle (1990) methodology with a few modifications. Approximately $100 \mathrm{mg}$ of leaf tissue was measured from each sample and pulverized in a mortar chilled with liquid nitrogen. Then, $1.2 \mathrm{~mL}$ of $3 \%$ CTAB buffer was added and the sample was further crushed. After transferring this solution to a $2 \mathrm{~mL}$ microcentrifuge tube, the protocol was followed without further modifications (Doyle and Doyle, 1990). For the DNA extraction from herbarium samples, we used a DNeasy Plant Mini Kit (Qiagen, Germantown, MD) following the manufacturer's recommended procedures.

DNA AMPLIFICATION. The polymerase chain reaction (PCR) amplifications of mat $K$ and $p s b A-t r n H$ regions were conducted using primers suggested by the Barcode of Life Data System (BOLD). For matk: MatK-1RKIM-f and MatK-3FKIM-r (K.J. Kim, unpublished), and for psbA-trnH: trnHf_05 (Tate and Simpson, 2003) and psbA3_f (Sang et al., 1997) were used (Table 1). For the amplification of the ITS region, the primers used were: ITS-u1 and ITS-u2 (Cheng et al., 2016), as well as ITS-Leu1 and ITS4 (Baum et al., 1998; White et al., 1990) (Table 1). The reaction for each sample included $5 \mu \mathrm{L}$ of Promega buffer 1X (Promega, Madison, WI), $5 \mu \mathrm{L}$ of $5 \mathrm{~mm}$ $\mathrm{MgCl}_{2}, 1 \mu \mathrm{L} 0.2 \mathrm{~mm}$ dNTPs, $1 \mu \mathrm{L}$ of $0.2 \mu \mathrm{M}$ forward and reverse primers, $0.2 \mu \mathrm{L}$ of Promega GoTaq polymerase (1 unit), and $0.75 \mu \mathrm{L}$ of dimethyl sulfoxide $(3 \%)$ in a final volume of $25 \mu \mathrm{L}$. The thermo-cycling regimens used in the amplification of each region were: $94{ }^{\circ} \mathrm{C}$ for $1 \mathrm{~min}$ followed by 45 cycles of $94{ }^{\circ} \mathrm{C}$ for $30 \mathrm{~s}, 52^{\circ} \mathrm{C}$ for $1 \mathrm{~min}, 72^{\circ} \mathrm{C}$ for $1 \mathrm{~min}$ with a final single cycle of $72{ }^{\circ} \mathrm{C}$ for $10 \mathrm{~min}$ for $\mathrm{mat} K ; 94^{\circ} \mathrm{C}$ for $45 \mathrm{~s}$, followed by 45 cycles of $94{ }^{\circ} \mathrm{C}$ for $30 \mathrm{~s}, 48^{\circ} \mathrm{C}$ for $1 \mathrm{~min}, 72^{\circ} \mathrm{C}$ for $40 \mathrm{~s}$ with a final 
Table 1. Primers used for this study. Primers where selected from the Barcode of Life Data System (BOLD) primer database (Ratnasingham and Hebert, 2007).

\begin{tabular}{llcc}
\hline Primer & \multicolumn{1}{c}{${\text { Sequence 5' }{ }^{\prime} \text { 3 }^{\prime}}^{\prime}$} & Primer length (bp) & Reference \\
\hline ITS-u1 (f) & GGAAGKARAAGTCGTAACAAGG & 22 & Cheng et al., 2016 \\
ITS-u4 (r) & RGTTTCTTTTCCTCCGCTTA & 20 & Cheng et al., 2016 \\
ITS leu & GTCCACTGAACCTTATCATTTAG & 23 & Urbatsch et al., 2000 \\
ITS 4 & TCCTCCGCTTATTGATATGC & 20 & White et al., 1990 \\
PsbA (f) & GTTATGCATGAACGTAATGCTC & 22 & Sang et al., 1997 \\
trnH (r) & CGCGCATGGTGGATTCACAATCC & 23 & Tate and Simpson, 2003 \\
MatK-1RKIM (f) & ACCCAGTCCATCTGGAAATCTTGGTTC & 27 & K.J. Kim, unpublished data \\
MatK-3FKIM (r) & CGTACAGTACTTTTGTGTTTACGAG & 25 & K.J. Kim, unpublished data \\
\hline
\end{tabular}

single cycle of $72{ }^{\circ} \mathrm{C}$ for $10 \mathrm{~min}$ for $p s b A$-trnH; and $94{ }^{\circ} \mathrm{C}$ for $45 \mathrm{~s}$, followed by 45 cycles of $94^{\circ} \mathrm{C}$ for $45 \mathrm{~s}, 48^{\circ} \mathrm{C}$ for $40 \mathrm{~s}$, $72{ }^{\circ} \mathrm{C}$ for $1 \mathrm{~min}$ with a final single cycle of $72^{\circ} \mathrm{C}$ for $10 \mathrm{~min}$ for ITS. Five microliters of each PCR product was visualized in a $1 \%$ agarose gel and the rest of the PCR product was then purified using the QIAquick PCR Purification kit (Qiagen) following manufacturer's protocol. The purified samples were then sent to the Genomic Science Laboratory at North Carolina State University (Raleigh) for Sanger sequencing following their protocols.

DAta AnAlysis. Sequences were aligned and manually edited using BioEdit version 7.1.9 (Hall, 1999). The alignment of each region was performed by ClustalX in BioEdit. A pairwise distance and a neighbor joining (NJ) analysis were then performed for each marker using MEGA verson 7.0.21 (Kumar et al., 2016). The pairwise distance data were used to compare relationships between genera and species. Sequence identifier version 1.8 and SequenceMatrix version 1.8 (Vaidya et al., 2011) were used to concatenate the barcode regions, and covert them to Nexus forma. Afterward, the file with the concatenated sequences was exported to PAUP version 4.0 (Swofford, 2002) in which a NJ analysis with 100 bootstraps was performed.

\section{Results}

A total of 72 fresh or dried samples were collected (Table 2), of which 66 samples were successfully amplified. PCR amplification success was higher for $m a t K$, followed by $p s A$-trnH and ITS with $91 \%, 88 \%$, and $87 \%$, respectively. In contrast, sequencing success was higher for $p s b A-t r n H$ followed by matK and ITS with $89 \%, 88 \%$, and $85 \%$, respectively. The length of the alignments was $742 \mathrm{bp}, 679 \mathrm{bp}$, and $688 \mathrm{bp}$ for matK, psbA-trnH, and ITS, respectively. Of these regions, ITS provided the highest variability, and matK was the most conserved region. All sequences from this study have been deposited in GenBank (Table 2).

\section{Pairwise distances}

The pairwise distance range was 0.000 to $0.017,0.000$ to 0.054 , and 0.007 to 0.088 for matK, psbA-trnH, and ITS, respectively. The outgroup pairwise distance range was 0.166 to $0.296,0.350$ to 0.670 , and $0.172-0.467$ for $m a t K$, psbA-trnH, and ITS, respectively. In all three markers, the genus that showed the highest pairwise distance between its species was Solanum, with $0.017,0.054$, and 0.088 for matk, trnH-psbA, and $I T S$, respectively. The genus that displayed the least pairwise distance between its species was Capsicum with 0.000 for the chloroplast barcodes while for ITS the genera that exhibited the least pairwise distance were Datura and Cestrum, both with 0.007 (Supplemental Tables 1-3).

\section{Neighbor joining analysis}

МАтк. The matk barcode region was able to distinguish 15 specimens at the species level, and in other cases, it was only able to discriminate at genus level (Fig. 1). In the NJ analysis, mat $K$ was able to distinguish individuals at the species level of G. elegans and most Solanum species. However, species from Physalis, Capsicum, Brugmansia, Datura, Brunfelsia, and Cestrum could not be differentiated.

PSBA-TRNH. The NJ analysis of $p s b A$-trnH showed better discrimination at the species level compared with matK (Fig. 2). Most species were separated into their respective clades except for those of the genera Brugmansia, Capsicum, Cestrum, and Physalis. For Physalis species, this barcode region showed better resolution than mat $K$ but was still not able to discriminate well at the species level. Other samples that could not be grouped into separate clades were those of the species $S$. erianthum, $S$. rugosum, and $S$. polygamum, which were grouped into a single clade. In addition, an unknown Physalis species [Table 2 (no. 27)] was recovered out of the $P$. angulata and $P$. pubescens clades.

ITS. The ITS barcode region showed higher variability among individuals in comparison with matk and psbA-trnH (Fig. 3). It was able to identify, used alone, even more species than $p s b$-trnH. Although more resolution is needed to have a more reliable discrimination between Cestrum, Capsicum, Datura, and Physalis species. In contrast with the other barcode regions, the specimens of $S$. erianthum, $S$. polygamum, and $S$. rugosum [Table 2 (no. 39, 46, and 47, respectively)] were able to be separated into clades by species. In contrast, $S$. polygamum and $S$. eranthum grouped into the same clade. Meanwhile, $S$. erianthum grouped in the Solanum rugosum clade.

Concatenated ANALYSIS. All three barcode regions were concatenated to increase discrimination (Fig. 4). The concatenated sequences had a length range between 1984 to $2109 \mathrm{bp}$. A total of 43 Solanaceae were included in the concatenated analysis. The genera Capsicum, Solanum, Brugmansia, Datura, Cestrum, Brunfelsia, and Physalis were grouped by clades as shown in Fig. 4. Solanum was recovered close to Cestrum, and these genera were closely related to Acnistus arborescens in comparison with the other genera. Similarly, Brugmansia, Datura, Solandra, and Lycium were recovered closely related to each other. A notable relationship was Browallia americana with Cestrum, whereas Brunfelsia was more closely related to these two genera in comparison with the rest of the species. Moreover, Physalis grouped into a single clade separate from the other clades. 


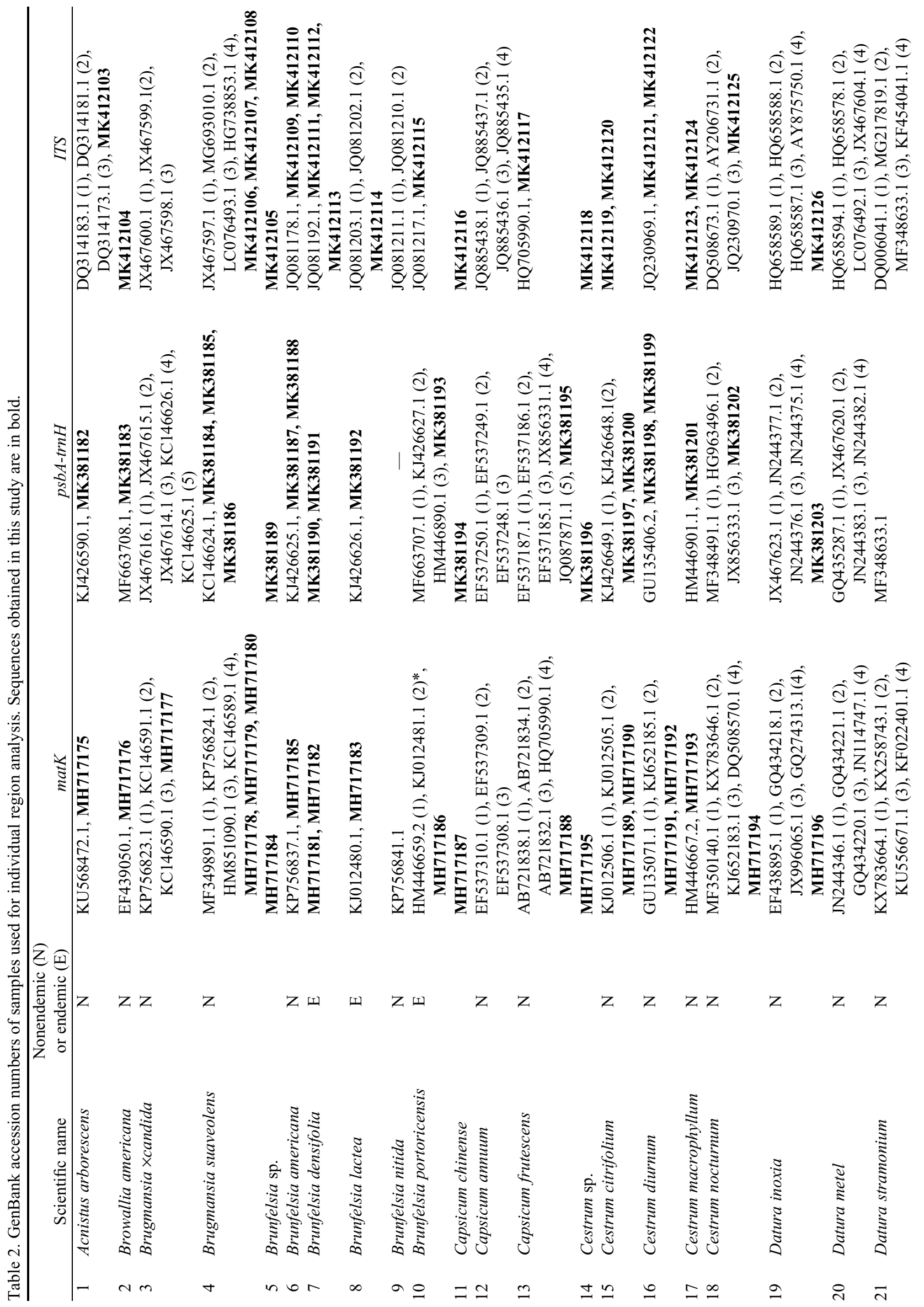




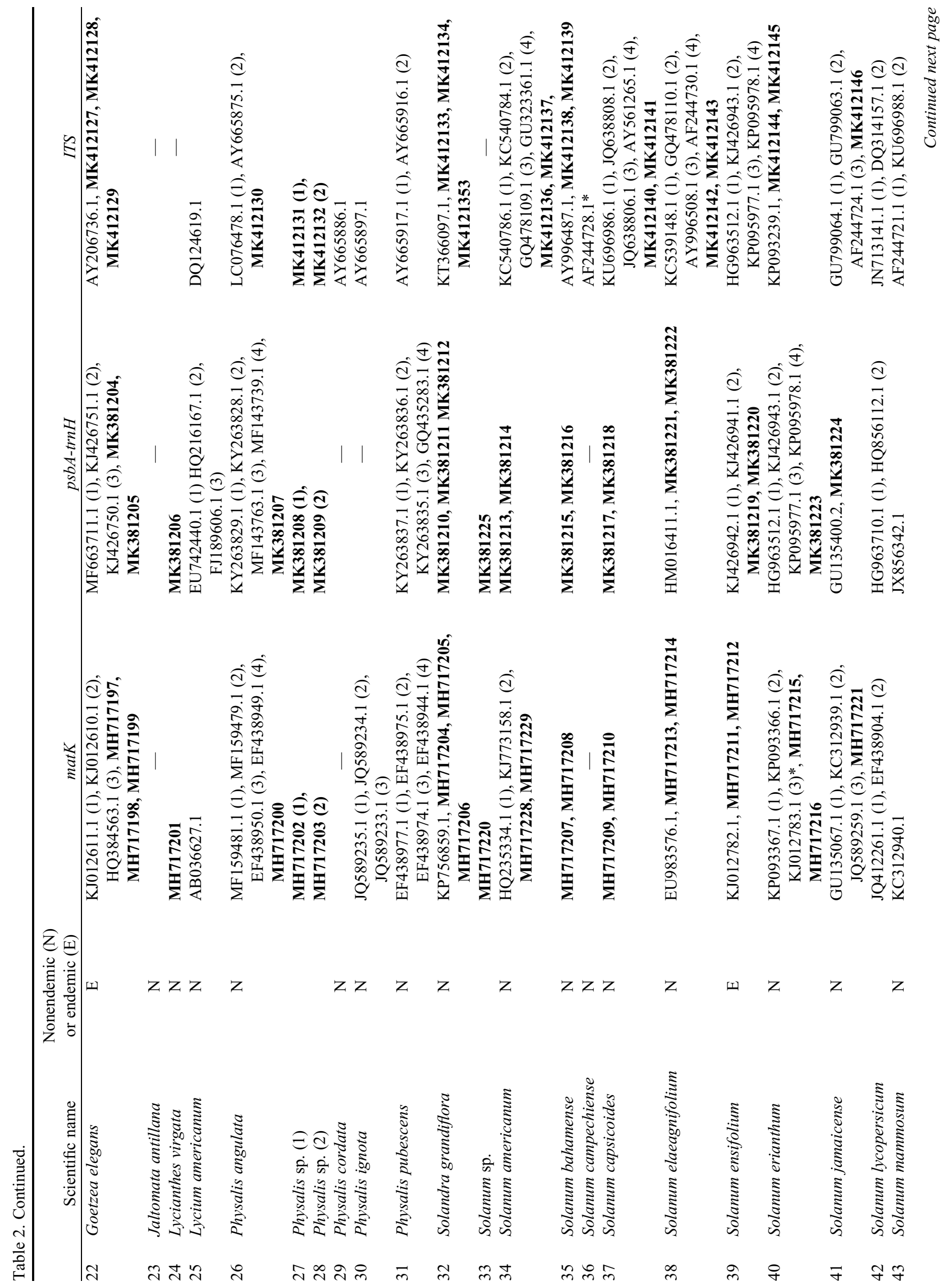




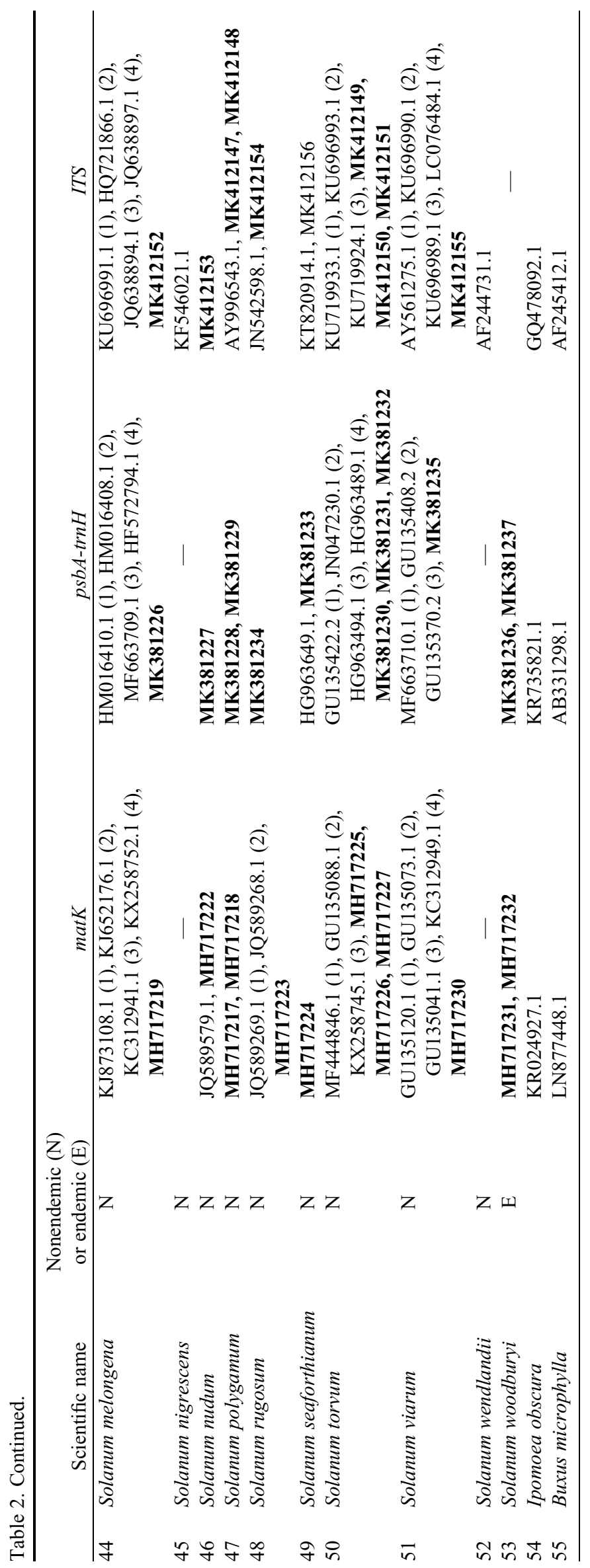

\section{Discussion}

The main purpose of this study was to obtain DNA sequence information from DNA barcoding loci, and to understand the feasibility of using DNA barcoding to identify Solanaceae specimens in Puerto Rico, including endemic and endangered species. An additional objective was to ascertain which DNA barcode marker, individually or in combination, can provide greater discrimination within Solanaceae, which then can help in future studies or conservation efforts.

ENDEMic SPECiEs discrimination. Puerto Rico has six endemic Solanaceae species: $B$. densifolia, B. lactea, B. portoricensis, G. elegans, $S$. ensifolium, and $S$. woodburyi [Table 2 (no. 7, 8, 10, 22, 39, and 53)]. DNA barcoding of Brunfelsia species has shown discrimination at the species level for both chloroplast and nuclear barcodes, especially when the barcodes are combined (Filipowicz and Renner, 2012). Brunfelsia consists of 50 species, high endemism, and a wide distribution in South America and the Antilles. It has been suggested that the adaptation of endemic species of Brunfelsia to certain habitats will contribute to the successful species identification within this genus (Filipowicz and Renner, 2012; Filipowicz et al., 2012). Our study also showed good discrimination of the genus Brunfelsia using all three barcodes combined (Fig. 4) or using only two barcodes, either ITS/matK or ITS/psba-trnH (Supplemental Figs. 1 and 2). In fact, species of Brunfelsia could be discriminated only using the ITS barcode (Fig. 3) thus do not require assessment of other DNA barcodes.

Firedrich von Wettstein (1895-1945) proposed that Goetzea was part of the Solanaceae. Subsequently, Goetzea was classified by different authors in its own family, the Goetzeaceae (Carlquist, 1988; Cronquist, 1981; Dahlgren, 1980). However, morphological and molecular studies have placed Goetzea once again as part of the Solanaceae (Fay et al., 1998; Olmstead et al., 1999; Zona, 1989). This demonstrates the important impact molecular studies have had on the taxonomy of this genus. In this study, G. elegans [Table 2 (no. 22)] was easily identified using the chloroplast and the nuclear markers (Figs. 1-3). This genus consists of two species, G. elegans and G. ekmanii, and the latter is endemic to the Dominican Republic (Liogier, 1995), and material was not available to include it in this study. Additional research is needed to determine if DNA barcoding can be successfully used to discriminate between these two species.

The critically endangered Puerto Rican endemic species $S$. ensifolium [Table 2 (no. 39)] was found in neither Cayey nor in Florida (Puerto Rico), thus the status of this plant in the wild is unknown (Vargas, 2015). Further work is needed to propagate the plant and to assess if the species is present in other parts of the island. In the wild, this plant can be confused with $S$. bahamense when there are no flowers or fruit (StricklandConstable et al., 2010), which makes DNA barcoding important for identifying sterile specimens of this species. In our study, it was demonstrated that matK or $p s b A-t r n H$, individually or in combination, can discriminate between these morphologically similar species (Figs. 1 and 2, Supplemental Fig. 3). Unfortunately, amplification and sequencing of the nuclear region ITS did not work for $S$. ensifolium, nor for Lyciantes virgata, $S$. jamaiscensis, Solanum sp. 49, and $S$. woodburyi, even with the use of different primer sets.

NONENDEMIC SPECIES DISCRIMINATION. Although $S$. woodburyi [Table 2 (no. 53)] is not considered an endangered 


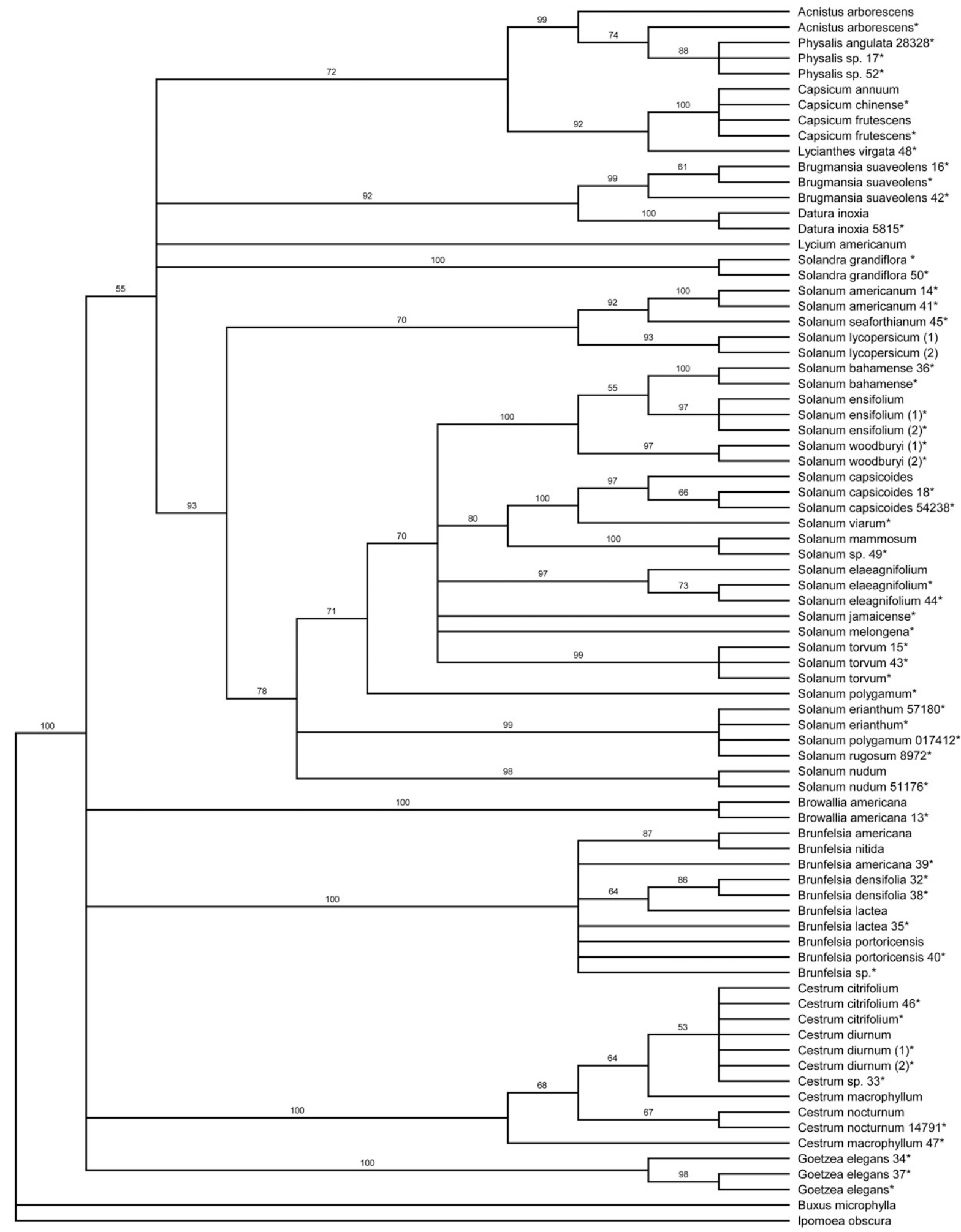

Fig. 1. Phylogenetic neighbor joining analysis based on the $m a t K$ barcode. Bootstraps scores are shown (100 replicates, $\geq 50 \%$ ) for each branch. Samples with sequences obtained in this study are depicted with an asterisk $(*)$. Discrimination at genus level can be observed using $\operatorname{matK}$ barcode.

species, it is rare and its known distribution is limited to Sierra de Luquillo (Axelrod, 2011). This is the first time $S$. woodburyi has been sampled in a molecular study. With the successful analysis of the chloroplast barcodes matK and $p s b A$-trnH, our analysis shows a close phylogenetic relationship between $S$. woodburyi, S. ensifolium, and S. bahamense (Figs. 1 and 2). We suggest that $S$. woodburyi might be part of the Bahamense clade. Using either matK or psbA-trnH, specimens of $S$. woodburyi can be successfully discriminated at the species level. The ITS region of $S$. woodburyi was not able to be amplified. 


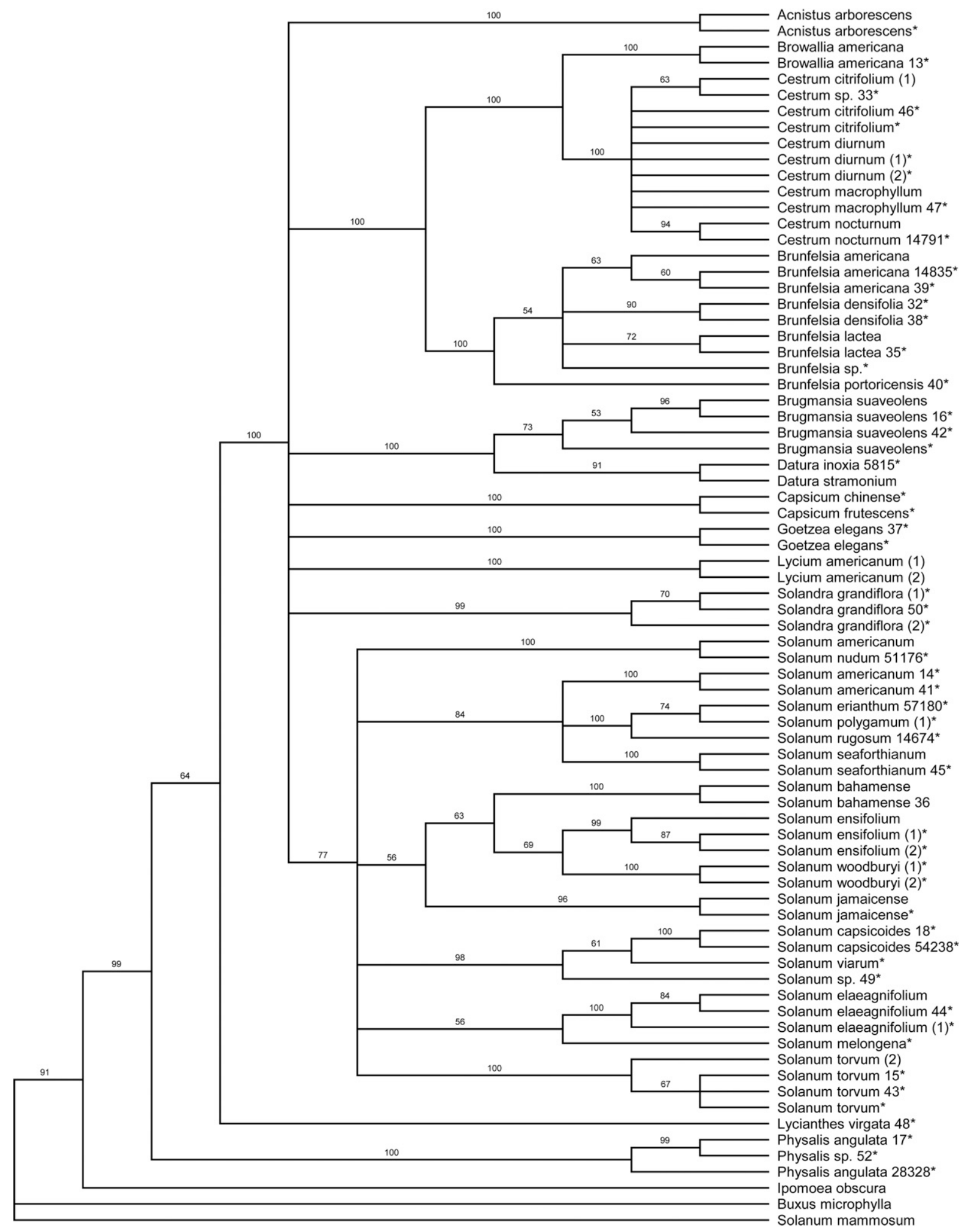

Fig. 2. Phylogenetic neighbor joining analysis based on the $p s b A$-trn $H$ barcode. Bootstraps scores are shown (100 replicates, $\geq 50 \%$ ) for each branch. Samples with sequences obtained in this study are depicted with an asterisk $\left(^{*}\right)$. Discrimination at genus and species level can be observed using $p s b A$-trn $H$ barcode.

Similar results were obtained with the species $S$. erianthum, S. polygamum, and S. rugosum [Table 2 (no. 40, 47, and 48)]. These three species were grouped in the same clade with the chloroplast barcodes, but the nuclear barcode ITS displayed more variability (Fig. 3). This information, interestingly, was used to rectify an error, which occurred during collection of the field samples. A leaf sample collected by a collaborator (employee of the Department of Natural Resources) was first labeled as Tabacón, which is the common name for both $S$. rugosum and $S$. erianthum. It was subsequently labeled as $S$. 


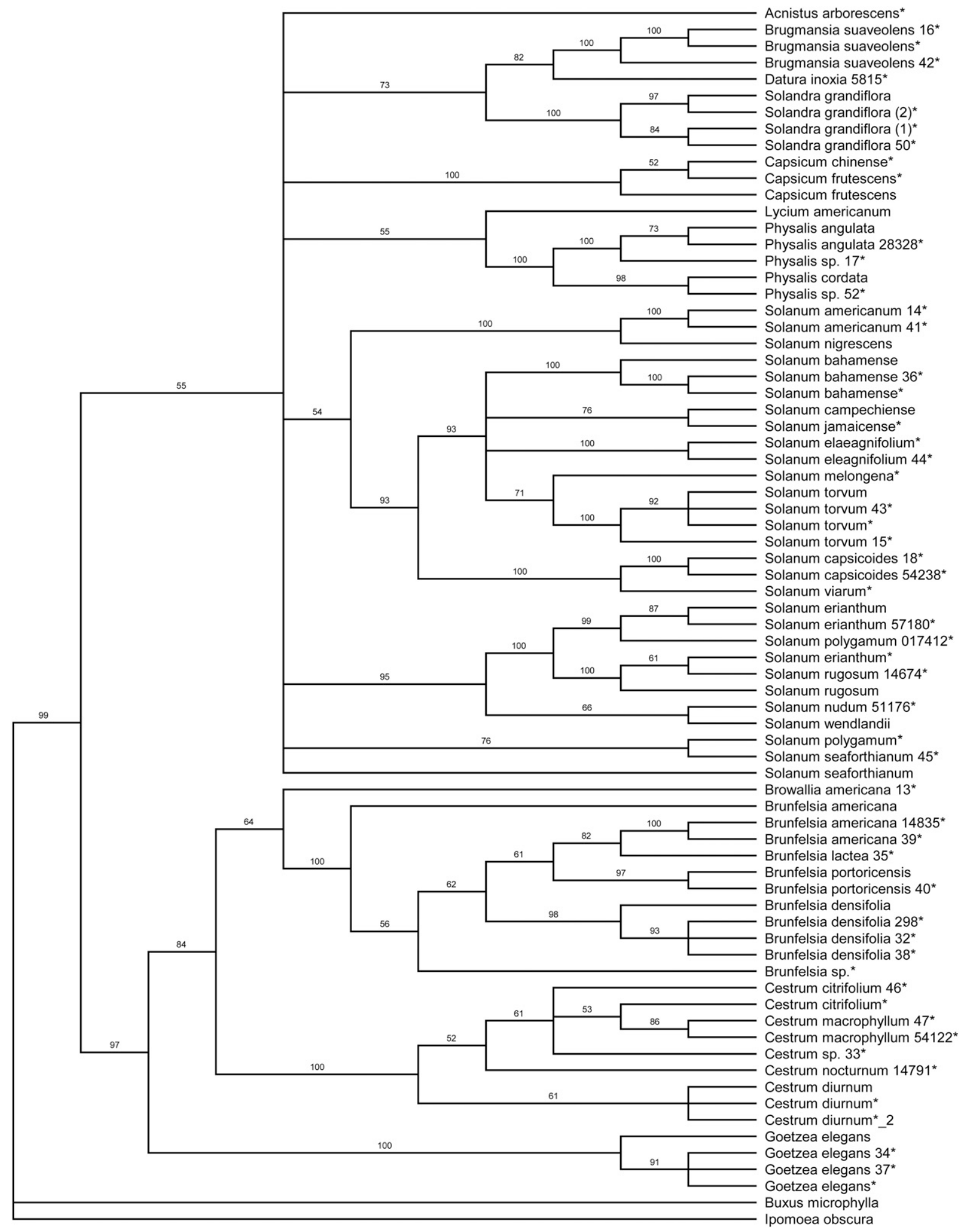

Fig. 3. Phylogenetic neighbor joining analysis based on the ITS (internal transcribed spacer) barcode. Bootstraps scores are shown (100 replicates, $\geq 50 \%$ ) for each branch. Samples with sequences obtained in this study are depicted with an asterisk (*). Discrimination at species level was observed using ITS barcode.

erianthum for our study. Upon analysis of the ITS region, we are able to identify the sample as $S$. rugosum, which is found in wet or moist areas at high elevations. In contrast, $S$. erianthum is found in dry limestone areas. Because the sample was obtained from Cayey, which is an area of high elevation and moisture, we were able to reliably identify the sample correctly as $S$. rugosum.

Discrimination OF agRiCULTURALlY VALUABLE CROPS. This study includes six agriculturally valuable crops, which are Capsicum annuum, C. frutescens, C. chinense, S. lycopersicum, 


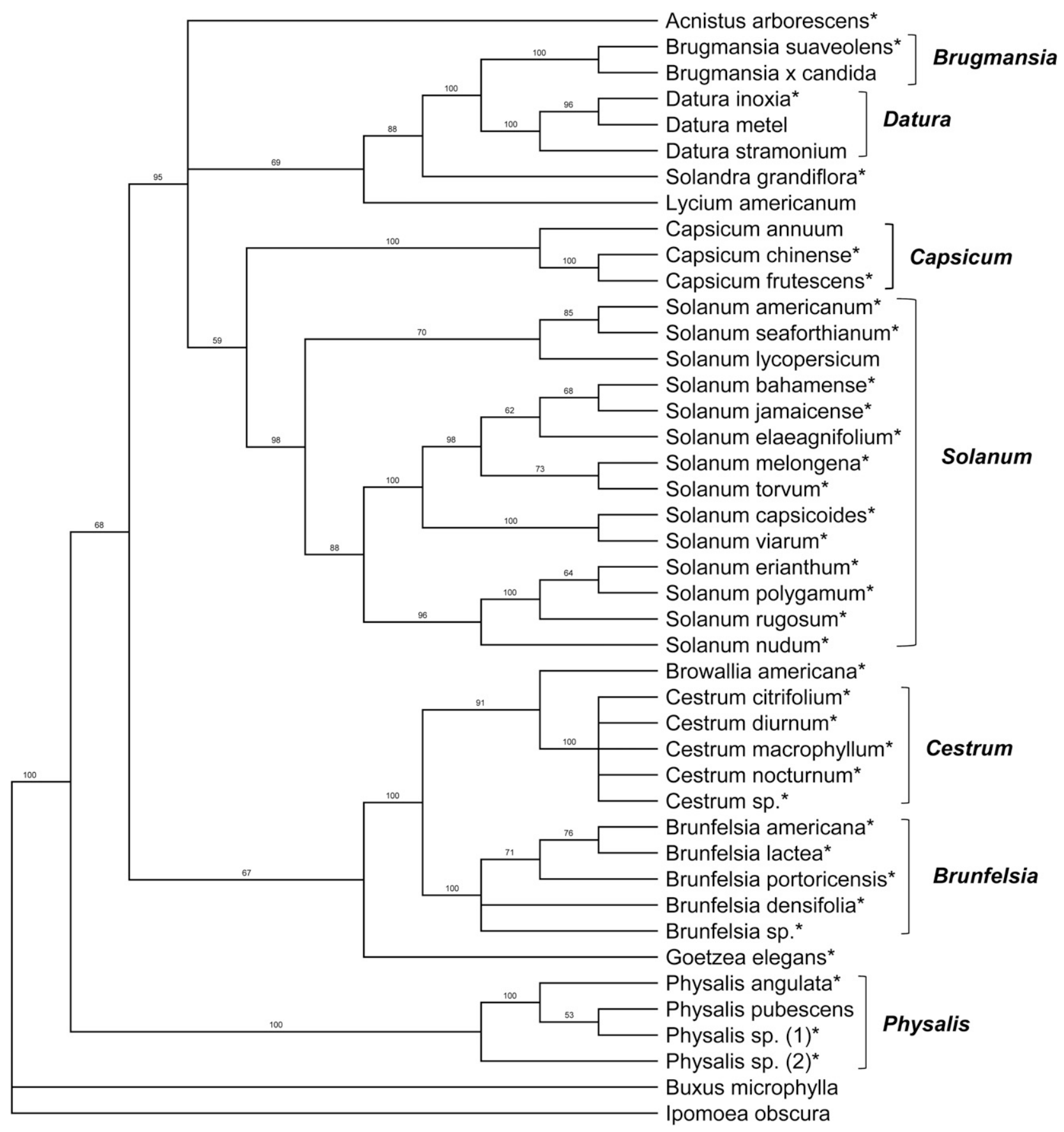

Fig. 4. Neighbor joining analysis of the concatenated sequences of $I T S+m a t K+p s b A-t r n H$. Samples with sequences obtained in this study are depicted with an asterisk $(*)$. A consensus of sequences was obtained for each species. Genera grouped by clades were designated with their respectively genus.

S. melongena, and Physalis pubescens. The genus that showed least species discrimination in our study was Capsicum, which is consistent with previous studies (Olmstead et al., 2008; Walsh and Hoot, 2001). However, the concatenated phylogenetic analysis showed better resolution in species discrimination of the Capsicum species compared with the single and double DNA barcode analysis (Fig. 4). Capsicum is considered to be native to the new world and domesticated by Native Americans (Moscone et al., 2007). As a result, in comparison with other Solanaceae species, Capsicum species have been more recently diverged, thus making species identification with only chloroplast barcodes not feasible. In Puerto Rico, the most cultivated and consumed Capsicum species are C. chinense, $C$. annuum, and $C$. frutescens [Table 2 (no. 11, 12, and 13)]. These three species are some of the most economically important crops of this genus (Carrizo García et al., 2016). In the present study, ITS showed more discrimination between $C$. chinense, $C$. annuum, and $C$. frutescens, with less variability observed between C. chinense and C. frutescens (Fig. 3). Previously, Walsh and Hoot (2001) studied the species relationships of Capsicum using other chloroplasts regions and the nuclear region, and obtained similar results. Although the chloroplast 
region was not able to discriminate between species, the nuclear region was able to provide significant variation to discriminate at species level.

S. lycopersicum is easily discriminated with individual and concatenated DNA barcodes in this study. A close relationship between $S$. lycopersicum with $S$. seafortianum and $S$. americanum was observed in individial and concatenated phylogenetic analysis, similar to previous studies (Marshall et al., 2001; Melotto-Passarin et al., 2008; Weese and Bohs, 2007). In all of these studies the closest species to $S$. lycopersicum was $S$. tuberosum (potato), and as a result, $S$. lycopersicum has been considered part of the potato clade (Bohs, 2005). Moreover, $S$. melongena showed a closer relationship with $S$. elaeagnifolium when evaluated with the chloroplast DNA barcodes. This relationship has been observed in previous phylogenics analyses that included chloroplast and nuclear DNA barcodes (Weese and Bohs, 2007; Zhang et al., 2013). In contrast, we observed a slightly closer relationship with $S$. torvum in the ITS and the concatenated phylogenetic analyses.

Another agriculturally important crop genus included in this study is Physalis, represented by $P$. pubescens and $P$. angulata. Specimens of Physalis are difficult to identify to species morphologically. A recent study shows that the chloroplast barcode $p s b A$-trnH was able to identify species of this genus (Feng et al., 2018). In our study, the DNA barcode that showed higher variability within Physalis was psbA-trnH, and when concatenated barcodes were used better discrimination was obtained (Fig. 4, Supplemental Fig. 2).

Additionally, specimens of unknown species were added to our study from different resources to test if the neighbor joining analysis of the different barcodes was capable of identifying them to species. These species were Solanum sp. 49, Physalis sp. 52, Physalis sp. 17, and Brunfelsia sp. For the sample Solanum sp. 49 [Table 2 (no. 33)] matK was able to group it with $S$. mammosum. The unknown samples Physalis sp. 52 and Physalis sp. 17 [Table 2 (no. 27 and 28)] were identified as Physalis ignota and Physalis pubescens, respectively (Fig. 4, Supplemental Fig. 2). Traditional taxonomic identification also confirmed that Solanum sp. 49 was Solanum mammosum. Although the Solanum and Physalis species were identified with DNA barcoding, the unknown Brunfelsia species [Table 2 (no. 5)] could not be matched to any of the Puerto Rico Solanaceae, nor ones from GenBank. This plant was collected from a private citizen's garden, who received it as a gift. Our results suggest that this plant does not correspond to any of the known Brunfelsia species from Puerto Rico and is not represented in the GenBank database.

\section{Conclusions}

Our study suggests that DNA barcoding can be used to identify the Solanaceae species of Puerto Rico. This molecular technique can be useful for future identification of the endemic and nonendemic plants of Puerto Rico for future conservation efforts or other studies. The majority of species were successfully identified with the barcodes individually. Matk was the most conserved region, and ITS the most variable region. As shown in previous studies, the $p s b A$-trnH barcode by itself showed good discrimination in species identification. The concatenated analysis of $m a t K, p s b A-t r n H$, and ITS gave more resolution in comparison with the other analyses.

\section{Literature Cited}

Axelrod, F.S. 2011. A systematic vademecum to the vascular plants of Puerto Rico. Bot. Res. Inst. Texas Press, Fort Worth, TX.

Baum, D.A., R.L. Small, and J.F. Wendel. 1998. Biogeography and floral evolution of baobabs (Adansonia, Bombacaceae) as inferred from multiple data sets. Syst. Biol. 47:181-207.

Bohs, L. 2005. Major clades in Solanum based on ndhF sequence data, p. 27-49. In: T. Keating, R. Hollowell, and V. Croat (eds.). A festschrift for William G. D'Arcy: The legacy of a taxonomist. Missouri Bot. Garden Press, Chicago, IL.

Bolson, M., E. de Camargo Smidt, M.L. Brotto, and V. Silva-Pereira. 2015. ITS and trnH-psbA as efficient DNA barcodes to identify threatened commercial woody angiosperms from southern Brazilian Atlantic rainforests. PLoS One 10:1-18.

Carlquist, S. 1988. Wood anatomy and relationships of Duckeodendraceae and Goetzeaceae. Intl. Assn. Wood Anatomists (IAWA) J. 9:3-12.

Carrizo García, C., M. Barfuss, E.M. Sehr, G.E. Barboza, R. Samuel, E.A. Moscone, and F. Ehrendorfer. 2016. Phylogenetic relationships, diversification and expansion of chili peppers (Capsicum, Solanaceae). Ann. Bot. 118:35-51.

CBOL Plant Working Group. 2009. A DNA barcode for land plants. Proc. Natl. Acad. Sci. USA 106:12794-12797.

Cheng, T., C. Xu, L. Lei, C. Li, Y. Zhang, and S. Zhou. 2016. Barcoding the kingdom Plantae: New PCR primers for ITS regions of plants with improved universality and specificity. Mol. Ecol. Resour. 16:138-149.

Collins, R.A. and R.H. Cruickshank. 2013. The seven deadly sins of DNA barcoding. Mol. Ecol. Resour. 13:969-975.

Cronquist, A. 1981. An integrated system of classification of flowering plants. Columbia Univ. Press, New York, NY.

Cywinska, A., F.F. Hunter, and P.D. Hebert. 2006. Identifying Canadian mosquito species through DNA barcodes. Med. Vet. Entomol. 20:413-424.

Dahlgren, R.M.T. 1980. A revised system of classification of the angiosperms. Bot. J. Linn. Soc. 80:91-124.

Di Pinto, A., P. Marchetti, A. Mottola, G. Bozzo, E. Bonerba, E. Ceci, M. Botarro, and G. Tantillo. 2015. Species identification in fish fillet products using DNA barcoding. Fish. Res. 170:9-13.

Doyle, J.J. and J.L. Doyle. 1990. Isolation of plant DNA from fresh tissue. Focus 12:13-15.

Dunning, L.T. and V. Savolainen. 2010. Broad-scale amplification of matK for DNA barcoding plants, a technical note. Bot. J. Linn. Soc. 164:1-9.

Fay, M.F., R.G. Olmstead, J.E. Richardson, E. Santiago, G.T. Prance, and M.W. Chase. 1998. Molecular data support the inclusion of Duckeodendron cestroides in Solanaceae. Kew Bull. 53:203-212.

Feliner, G.N. and J.A. Rosselló. 2007. Better the devil you know? Guidelines for insightful utilization of nrDNA ITS in specieslevel evolutionary studies in plants. Mol. Phylogenet. Evol. 44:911-919.

Feng, S., K. Jiao, Y. Zhu, H. Wang, M. Jiang, and H. Wang. 2018. Molecular identification of species of Physalis (Solanaceae) using a candidate DNA barcode: The chloroplast psbA-trnH intergenic region. Genome 61:15-20.

Filipowicz, N., M. Nee, and S. Renner. 2012. Description and molecular diagnosis of a new species of Brunfelsia (Solanaceae) from the Bolivian and Argentinean Andes. PhytoKeys 10:83.

Filipowicz, N. and S.S. Renner. 2012. Brunfelsia (Solanaceae): A genus evenly divided between South America and radiations on Cuba and other Antillean islands. Mol. Phylogenet. Evol. 64:1-11.

González, M.A., C. Baraloto, J. Engel, S.A. Mori, P. Pétronelli, B. Riéra, A. Roger, C. Thebaud, and J. Chavez. 2009. Identification of amazonian trees with DNA barcodes. PLoS One 4:e7483.

Hall, T.T. 1999. BioEdit: A user-friendly biological sequence alignment editor and analysis program for Windows 95/98/NT. Nucl. Acids Symp. Ser 41:95-98. 
Hebert, P.D.N., A. Cywinska, S.L. Ball, and J.R. deWaard. 2003. Biological identifications through DNA barcodes. Proc. Biol. Sci. 270:313-321.

Hebert, P.D.N., E.H. Penton, J.M. Burns, D.H. Janzen, and W. Hallwachs. 2004. Ten species in one: DNA barcoding reveals cryptic species in the neotropical skipper butterfly Astraptes fulgerator. Proc. Natl. Acad. Sci. USA 101:14812-14817.

Helmer, E.H., O. Ramos, T. López, M. Quinones, and W. Diaz. 2002. Mapping the forest type and land cover of Puerto Rico, A component of the Caribbean biodiversity hotspot. Caribb. J. Sci. 38:165-183.

Hollingsworth, P.M. 2011. Refining the DNA barcode for land plants. Proc. Natl. Acad. Sci. USA 108:19451-19452.

Hollingsworth, P.M., S.W. Graham, and D.P. Little. 2011. Choosing and using a plant DNA barcode. PLoS One 6:e19254.

Howard, R.A. 1966. Notes on some plants of Puerto Rico. J. Arnold Arbor. 47:138-139.

Knapp, S. 2009. Synopsis and lectotypification of Solanum (Solanaceae) species endemic in the West Indies. An. Jardin Botanico Madr. 1979 66:65-84.

Kress, W.J. 2017. Plant DNA barcodes: Applications today and in the future. J. Syst. Evol. 55:291-307.

Kress, W.J. and D.L. Erickson. 2007. A two-locus global DNA barcode for land plants: The coding rbcL gene complements the non-coding trnH-psbA spacer region. PLoS One 2:e508.

Kress, W.J., D.L. Erickson, F. Jones, N.G. Swenson, R. Perez, E. Bermingham, and O. Sanjur. 2009. Plant DNA barcodes and a community phylogeny of a tropical forest dynamics plot in Panama. Proc. Natl. Acad. Sci. USA 106:18621-18626.

Kress, W.J., K.J. Wurdack, E.A. Zimmer, L.A. Weigt, and D.H. Janzen. 2005. Use of DNA barcodes to identify flowering plants. Proc. Natl. Acad. Sci. USA 102:8369-8374.

Kumar, S., G. Stecher, and K. Tamura. 2016. MEGA7: Molecular evolutionary genetics anaysis Version 7.0 for bigger datasets. Mol. Biol. Evol. 33:1870-1874.

Li, D.Z., L. Gao, H. Li, H. Wang, X. Ge, J. Liu, and G. Duan. 2011. Comparative analysis of a large dataset indicates that internal transcribed spacer (ITS) should be incorporated into the core barcode for seed plants. Proc. Natl. Acad. Sci. USA 108:19641-19646.

Li, X., Y. Yang, R. Henry, M. Rossetto, Y. Wang, and S. Chen. 2014. Plant DNA barcoding: From gene to genome. Biol. Rev. Camb. Philos. Soc. 90:157-166.

Liogier, H.A. 1995. Descriptive flora of Puerto Rico and adjacent islands. Univ. Puerto Rico Press, Rio Piedras, PR.

Marshall, J.A., S. Knapp, M.R. Davey, J.B. Power, E.C. Cocking, M.D. Bennett, and A. Cox. 2001. Molecular systematics of Solanum section Lycopersicum (Lycopersicon) using the nuclear ITS rDNA region. Theor. Appl. Genet. 103:1216-1222.

Melotto-Passarin, D.M., I.J. Berger, K. Dressano, V.F. De Martin, G. Conde, G.C. Oliveira, and H. Carrer. 2008. Phylogenetic relationships in Solanaceae and related species based on cpDNA sequence from plastid trnE-trnT region. Crop Breed. Appl. Biotechnol. 8:85-95.

Moscone, E.A., M. Scaldaferro, M. Grabiele, N.M. Cecchini, Y.S. García, R. Jarret, and F. Ehrendorfer. 2007. The evolution of chili peppers (Capsicum-Solanaceae): A cytogenetic perspective. Acta Hort. 745:137-170.

Muscarella, R., M. Uriarte, D. Erickson, N.G. Swenson, J.K. Zimmerman, and W.J. Kress. 2014. A well-resolved phylogeny of the trees of Puerto Rico based on DNA barcode sequence data. PLoS One 9:e112843.

Myers, N., R.A. Mittermeier, C.G. Mittermeier, G.A.B. da Fonsecaavo, and J. Kent. 2000. Biodiversity hotspots for conservation priorities. Nature 403:853-858.

Olmstead, R.G., V.F. Garcia, H.A. Migid, S.M. Collier, L. Bohs, and E. Santiago-Valentin. 2008. A molecular phylogeny of the Solanaceae. Taxon 57:1159-1181.
Olmstead, R.G., J.A. Sweere, R.E. Spangler, L. Bohs, and J.D. Palmer. 1999. Phylogeny and provisional classification of the Solanaceae based on chloroplast DNA, p. 111-137. In: J. Nee, M. Symon, D. Lester, and R. Jessop (eds.). Solanaceae IV: Advances in biology and utilization. Royal Botanic Gardens, London, UK.

Ratnasingham, S. and P.D. Herbert. 2007. BOLD: The barcode of life data system. Mol. Ecol. Notes 7:355-364.

Rolo, E.A., A.R. Oliveira, C.G. Dourado, A. Farinha, M.T. Rebelo, and D. Dias. 2013. Identification of sarcosaprophagous diptera species through DNA barcoding in wildlife forensics. Forensic Sci. Intl. 228:160-164.

Sang, T., D.J. Crawford, and T.F. Stuessy. 1997. Chloroplast DNA phylogeny, reticulate evolution, and biogeography of Paeonia (Paeoniaceae). Amer. J. Bot. 84:1120-1136.

Selvaraj, D., R.K. Sarma, and R. Sathishkumar. 2008. Phylogenetic analysis of chloroplast matK gene from Zingiberaceae for plant DNA barcoding. Bioinformation 3:24-27.

Spooner, D.M. 2009. DNA barcoding will frequently fail in complicated groups: An example in wild potatoes. Amer. J. Bot. 96:11771189.

Storchová, H. and M.S. Olson. 2007. The architecture of the chloroplast psbA-trnH non-coding region in angiosperms. Plant Syst. Evol. 268:235-256.

Strickland-Constable, R., H. Schneider, S.W. Ansell, S.J. Russell, and S. Knapp. 2010. Species identity in the Solanum bahamense species group (Solanaceae, Solanum subgenus Leptoslemonum). Taxon 59:209-226.

Swofford, D.L. 2002. PAUP*: Phylogenetic analysis using parsimony (*and other methods), version 4.0b3a. Sinauer Associates, Sunderland, MA.

Tate, J.A. and B.B. Simpson. 2003. Paraphyly of Tarasa (Malvaceae) and diverse origins of the polyploid species. Syst. Bot. 28:723-737.

Urbatsch, L.E., B.G. Baldwin, and M.J. Donoghue. 2000. Phylogeny of the coneflowers and relatives (Heliantheae: Asteraceae) based on nuclear rDNA internal transcribed spacer (ITS) sequences and chloroplast DNA restriction site data. Syst. Bot. 25:539-565.

U.S. Fish and Wildlife Service. 1985. Four plants given endangered species act protection. Endangered Species Tech. Bul. MB-815.

Vaidya, G., D.J. Lohman, and R. Meier. 2011. SeqenceMatrix: Cladistics multi-gene datasets with character set and codon information. Cladistics 27:171-180.

Vargas, M. 2013. Matabuey (Goetzea elegans) 5-year review: Summary and evaluation. 19 Jan. 2019. <https://ecos.fws.gov/docs/five_ year_review/doc4257.pdf>.

Vargas, M. 2015. Erubia (Solanum drymophilum) 5-year review: Summary and evaluation. 19 Jan. 2019. <https://ecos.fws.gov/docs/ five_year_review/doc4652.pdf>.

Walsh, B.M. and S.B. Hoot. 2001. Phylogenetic relationships of Capsicum (Solanaceae) using DNA sequences from two noncoding regions: The chloroplast atpB-rbcL spacer region and nuclear waxy introns. Intl. J. Plant Sci. 162:1409-1418.

Weese, T.L. and L. Bohs. 2007. A three-gene phylogeny of the genus Solanum (Solanaceae). Syst. Bot. 32:445-463.

White, T.J., T. Bruns, S. Lee, and J. Taylor. 1990. Amplification and direct sequencing of fungal ribosomal RNA genes for phylogenetics. In A guide to methods and applications. Academic Press, New York, NY.

Yu, J., J.H. Xue, and S.L. Zhou. 2011. New universal matK primers for DNA barcoding angiosperms. J. Syst. Evol. 49:176-181.

Zhang, W., X. Fan, S. Zhu, H. Zhao, and L. Fu. 2013. Species-specific identification from incomplete sampling: Applying DNA barcodes to monitor invasive solanum plants. PLoS One 8:e55927.

Zona, S. 1989. Leaf anatomy of the Goetzeaceae. Aliso J. Systematic Evol. Bot. 12:303-312. 


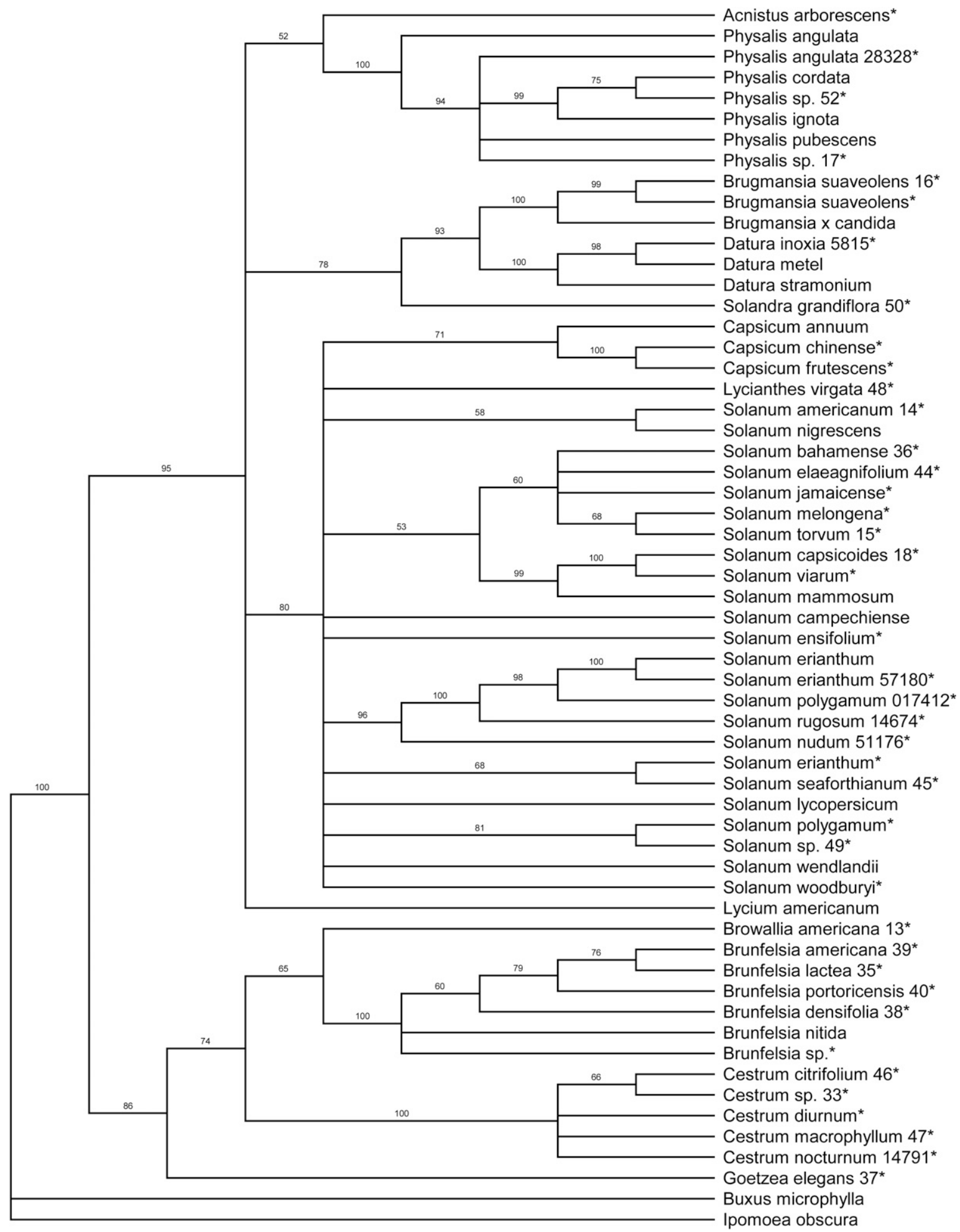

Supplemental Fig. 1. Neighbor joining analysis of the concatenated sequences of $I T S+$ matK. Bootstraps scores are shown (100 replicates, $\geq 50 \%)$ for each branch. 


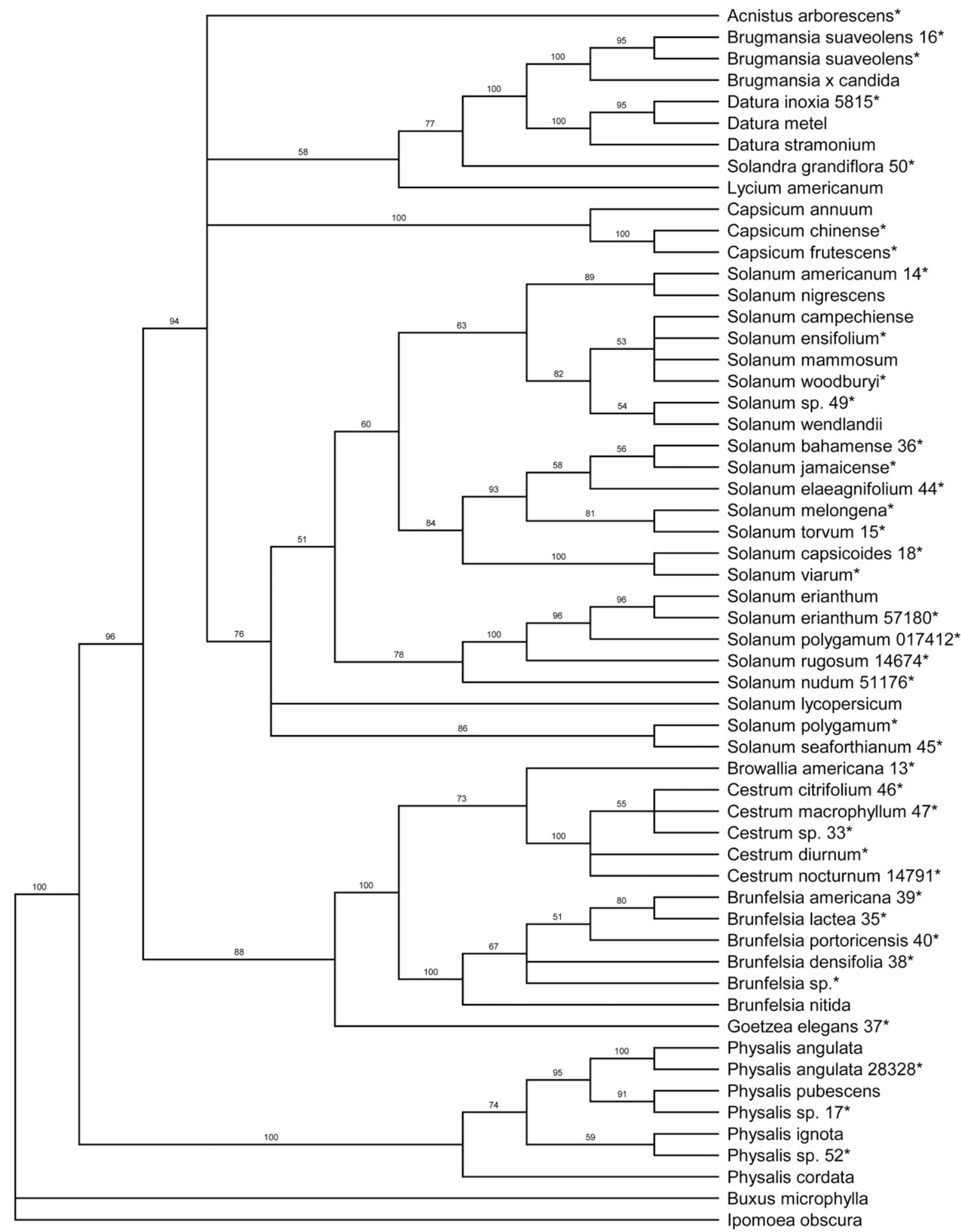

Supplemental Fig. 2. Neighbor joining analysis of the concatenated sequences of $I T S+p s b A$-trnH. Bootstraps scores are shown (100 replicates, $\geq 50 \%)$ for each branch. 


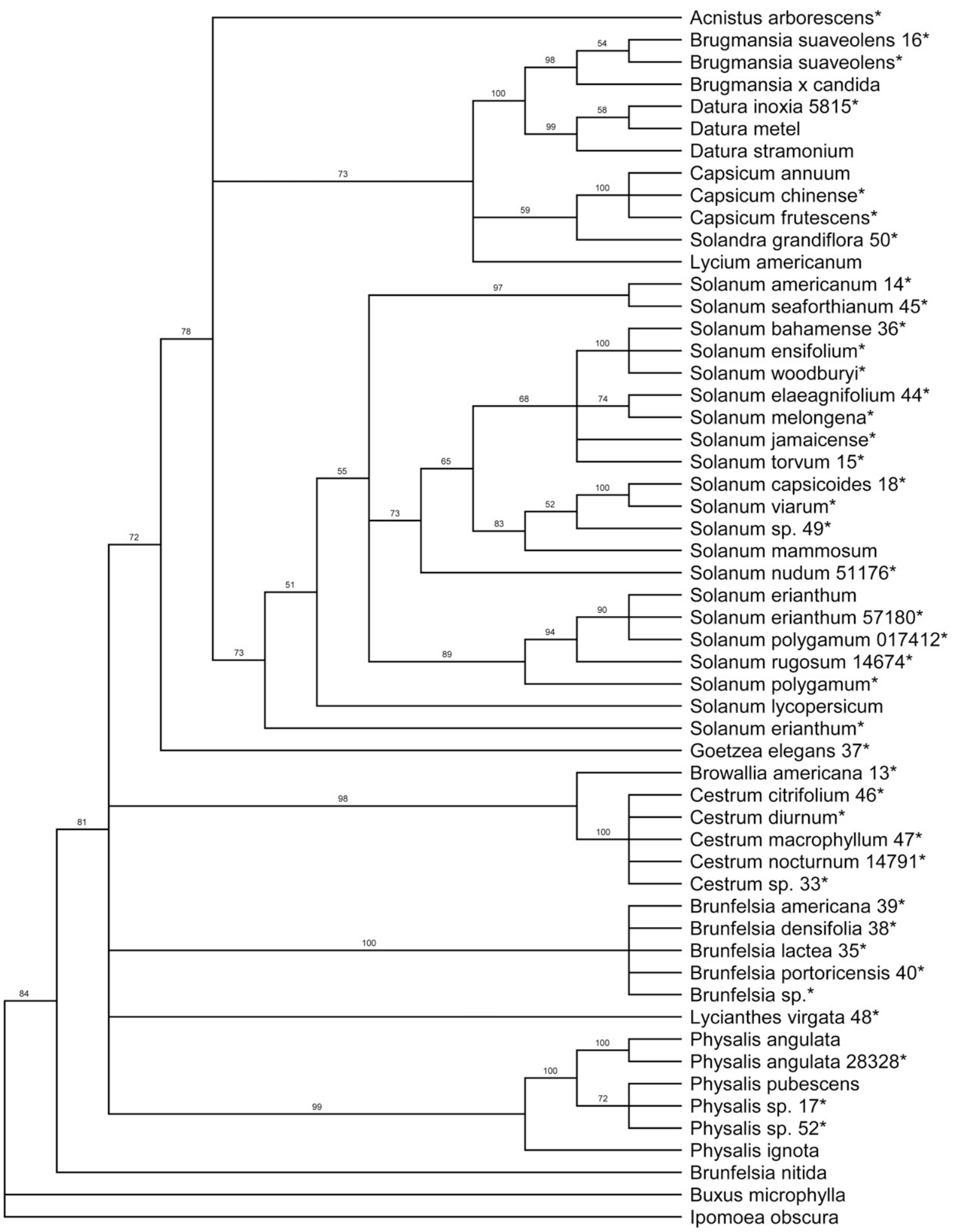

Supplemental Fig. 3. Neighbor joining analysis of the concatenated sequences of $m a t K+p s b A-t r n H$. Bootstraps scores are shown $(100$ replicates, $\geq 50 \%)$ for each branch. 
Supplemental Table 1. Interspecific and intraspecific pairwise distance for the MatK DNA barcode.

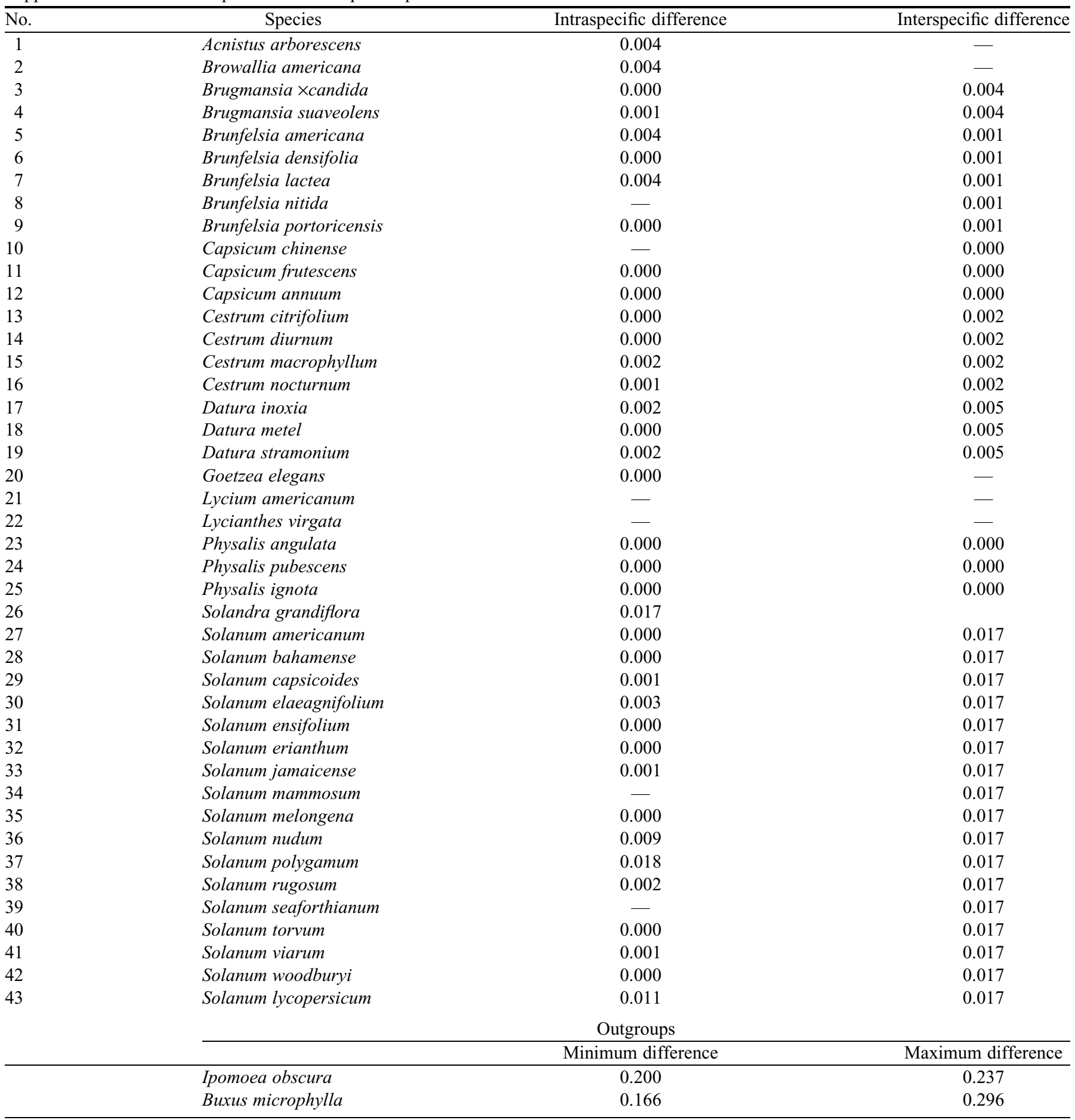


Supplemental Table 2. Interspecific and intraspecific pairwise distance for the ITS DNA barcode.

\begin{tabular}{|c|c|c|c|}
\hline No. & Species & Intraspecific difference & Interspecific difference \\
\hline 1 & Acnistus arborescens & 0.008 & - \\
\hline 3 & Brugmansia $\times$ candida & 0.000 & 0.015 \\
\hline 5 & Brunfelsia americana & 0.001 & 0.010 \\
\hline 6 & Brunfelsia densifolia & 0.000 & 0.010 \\
\hline 7 & Brunfelsia lactea & 0.000 & 0.010 \\
\hline 10 & Capsicum chinense & - & 0.050 \\
\hline 11 & Capsicum frutescens & 0.008 & 0.050 \\
\hline 12 & Capsicum annuum & 0.006 & 0.050 \\
\hline 13 & Cestrum citrifolium & 0.000 & 0.007 \\
\hline 14 & Cestrum diurnum & 0.005 & 0.007 \\
\hline 19 & Datura stramonium & 0.000 & 0.007 \\
\hline 20 & Goetzea elegans & 0.000 & - \\
\hline 21 & Lycium americanum & - & - \\
\hline 22 & Lycianthes virgata & - & - \\
\hline 23 & Physalis angulata & 0.016 & 0.011 \\
\hline 24 & Physalis pubescens & 0.000 & 0.011 \\
\hline 25 & Physalis cordata & - & 0.011 \\
\hline 26 & Physalis ignota & 0.000 & 0.011 \\
\hline 27 & Solandra grandiflora & 0.001 & - \\
\hline 28 & Solanum americanum & 0.005 & 0.088 \\
\hline 29 & Solanum bahamense & 0.011 & 0.088 \\
\hline 37 & Solanum nudum & - & 0.088 \\
\hline 38 & Solanum polygamum & 0.162 & 0.088 \\
\hline 39 & Solanum rugosum & 0.012 & 0.088 \\
\hline 40 & Solanum seaforthianum & 0.284 & 0.088 \\
\hline 41 & Solanum nigrescens & - & 0.088 \\
\hline 42 & Solanum torvum & 0.045 & 0.088 \\
\hline 43 & Solanum viarum & 0.011 & 0.088 \\
\hline 44 & Solanum wendlandii & - & 0.088 \\
\hline \multirow[t]{5}{*}{45} & Solanum lycopersicum & 0.000 & 0.088 \\
\hline & \multicolumn{3}{|c|}{ Outgroups } \\
\hline & & Minimum difference & Maximum difference \\
\hline & Ipomoea obscura & 0.172 & 0.392 \\
\hline & Buxus microphylla & 0.307 & 0.467 \\
\hline
\end{tabular}


Supplemental Table 3. Interspecific and intraspecific pairwise distance for the $p s b A$-trnH DNA barcode.

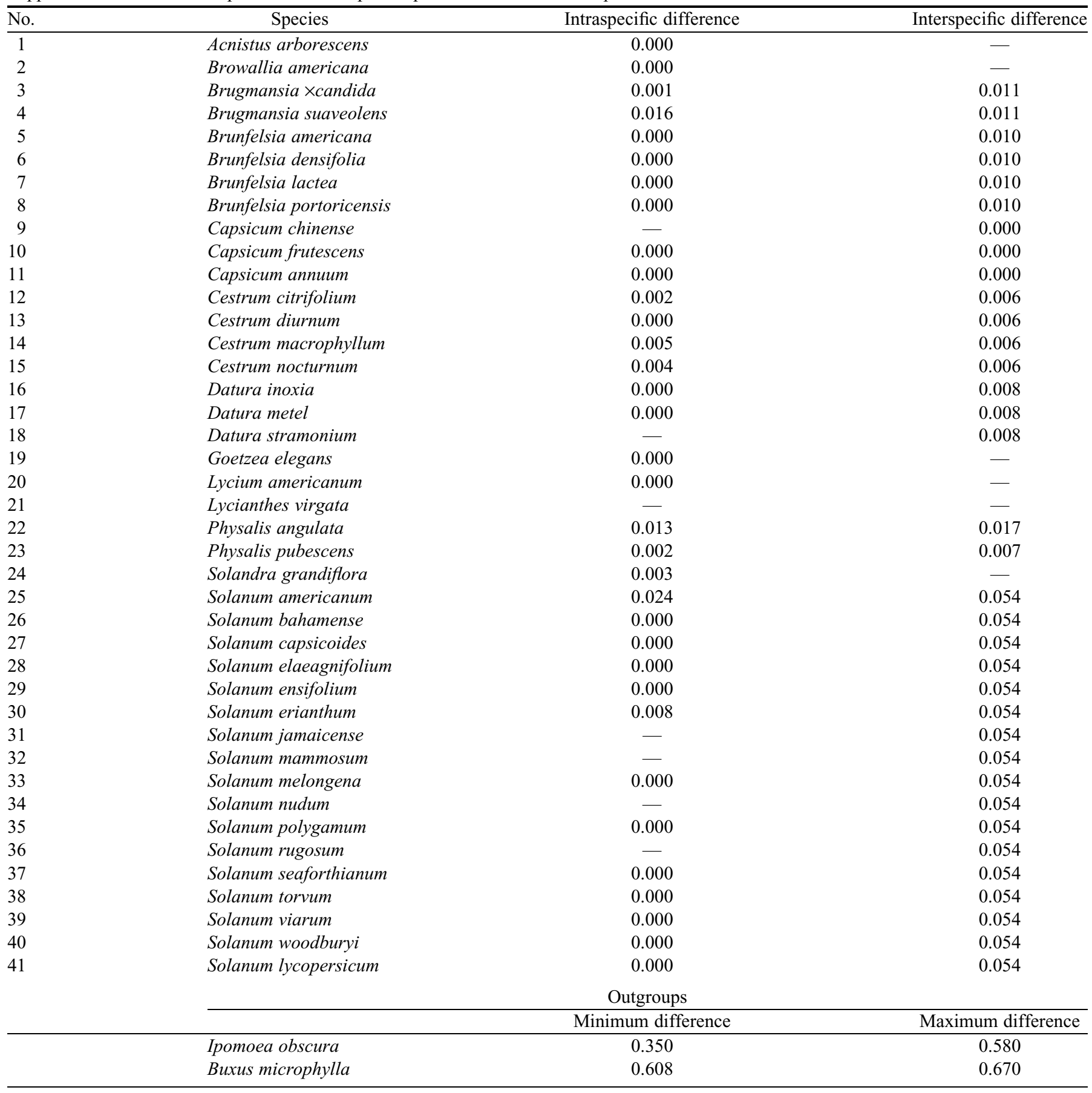

